\title{
Pacific media councils and cultural values: Safety valve or entrenched hegemony?
}

\section{ABSIRACIP}

Two countries in the South Pacific, Fiji and Papua New Guinea, have adopted contrasting media council models to self-regulate the media amid growing political and cultural pressures on the news industry. Projected as promoting media standards and professionalism and a model for the region, the realities have raised questions about whether such bodies are self-regulatory mechanisms genuinely working in the public interest in the Pacific or defending entrenched media and power relationships, some foreign, from pressure by island governments. There are also questions over whether codes of ethics promoted by the councils are effective as self-regulatory tools for the media. Exploring case studies such as media coverage of the controversial John Scott double murder case in Fiji, the Speight attempted coup and political crises in Papua New Guinea, this article examines these dilemmas and also whether codes of practice reflect regional 'Pacific way' cultural values, or are in fact adopted as part of globalisation.

\section{DAVID ROBIE}

Auckland University of Technology

\section{Introduction}

Jews media in South Pacific countries, as in many other nations, have faced

1 increasing criticism of professional and ethical standards. The criticism focuses on lack of professional training of journalists, poor education standards, 
lack of knowledge of the political and social institutions, cultural insensitivities, and a questionable grasp of ethical issues. The media, some argue, is Western and not the 'Pacific way'. Others, particularly politicians, are keen to introduce regulatory controls to 'rein in' the media (Singh, 2002). However, the media industry is quick to defend its integrity and, while acknowledging some shortcomings, insists self-regulation is best.

Towards the end of 2002, the press in Fiji faced some particularly nasty vitriol. Senator Mitieli Bulanauca branded local journalists as 'mad crazy loonies and stupid people' who needed to be 'trained, guided and directed' (Singh, 2002; Fiji journalists are 'mad, crazy loonies', says senator, 2002). He also described media as 'Satan's agents', arguing that editors, publishers, reporters and announcers were racist and naive amateurs. His brand of nastiness followed another Government senator, Reverend Tomasi Kanailagi, a former Methodist Church president, who singled out The Fiji Times and Fiji Television as alleged 'agents of evil' over an exposé about church finances. Although these views had a rather hysterical tone, they echoed more measured criticism a year earlier by media commentators and overseas current affairs programmes about the standard of crime reporting in Fiji at the time of a double murder in which Red Cross executive director John Scott and his partner were hacked to death. Serious ethical dilemmas were also exposed over coverage of George Speight's attempted coup in May 2000 (Cass, 2002; Field, 2002; Moala, 2001 127-133; Robie, 2001: 150-156). While media councils and self-regulation have become a new mantra in the Pacific, there remain questions of credibility. Fiji's selfregulatory body, the Media Council (Fiji) Ltd, was eager to defend the media against attacks such as the senators' 'preposterous' criticisms (Tarte, 2002; Hussain, 2002) but remained fairly muted on both the Scott murder case reporting and the Speight political crisis.

Two countries in the South Pacific, Fiji and Papua New Guinea, have adopted contrasting media council models to self-regulate the media (Robie, 1999a). Other countries such as Tonga are keen to follow the lead (Moala, 2000: 62). Projected as promoting media standards and professionalism and a model for the region, the realities of the media councils have raised questions about whether such bodies are self-regulatory mechanisms genuinely working in the public interest in the Pacific or merely defending entrenched media and power relationships, some foreign, from pressure by island governments. There are also questions over whether codes of ethics promoted by the councils are effective as self-regulatory tools for the media. This paper examines these 
dilemmas and also whether codes of practice reflect regional 'Pacific way' cultural values, or are in fact largely adopted as part of globalisation.

\section{Cultural hegemony and the Pacific}

Many powerful institutions, such as the Methodist Church in Fiji, and politicians in the Pacific believe there is no place for a Western-style free media and it should be held in check by Government legislation. The values encouraged by the media in the Pacific are regarded as 'universalism, materialism, individualism, secularism, competition, whiteness, self-centredness and [an] unrestrained display of ... emotions' (Thaman, 2001). This view has been well articulated by Tongan humanities professor Konai Helu Thaman:

In most Pacific towns today, whether it is Suva, Nuku'alofa, Apia or Port Vila, the most common theme/ideology that is carried by the different media is that of consumerism ... The underlining assumption seems to be that consumer democracy can be sold, especially to the poor and powerless, as a possible substitute for political democracy (ibid: 4).

According to Thaman, media has changed attitudes among the young with a message that respect for authority, especially elders and parents, are 'oldfashioned and uncool'. Yet there are other views such as those of another Tongan academic, 'I Futa Helu (1995: 2), who regard the media as an institution with a distinct morality and set of values of its own that contributes to developing democratic values in the region. These values are part of the morality of liberal democracy, for modern media culture is an institutional embodiment of freedom of expression and the right to be well and truly informed. But he warns:

And because liberal culture has not made any worthwhile impact on Pacific Islands societies, media will have to fight alone against the bigotry and discrimination of traditional privilege and cultural vested interests (ibid.: 3).

In his Cultural Writings, Antonio Gramsci (1971) developed an insight into the role of journalism in the organisation and manufacture of consent: the process by which hegemony (intellectual and moral leadership) operates. Writing from his own experiences as a journalist in Italy in the early part of the 20th century, Gramsci identified the importance of the media - 'publishing houses, political newspapers, periodicals of every kind', describing them as the 'most dynamic 104 PACIFIC JOURNALISM REVIEW 92003 
part' of the ideological structure of society. Michael Meadows sees Gramsci's interpretation of Marxism as closest to a theory of culture, an ideology defining a 'set of commonly-led ideas and assumptions, which enable particular ideas to predominate' (Meadows, 1998: 5) Gramscian views observe the operation of hegemony in mainstream media through the practices of journalism. They offer a theory of journalism as a series of practices implicitly part of the 'strategic management of information, ideas and therefore, culture' (ibid.: 7). Hence Thaman's view of a Western 'mirror' of Pacific culture through the media. She believes Pacific media and news institutions should reflect values such as consensus rather than majority decision-making, group rather than individual orientation, interpersonal relationships rather than personal confrontation, restraint rather than criticism, and cooperation rather than competition (Thaman, 2001: 10).

\section{Ethical issues and self-regulation}

The Fiji news media and police faced harsh criticism over their treatment of the John Scott double murder case (Panichi; Tapueluelu, 2001). Fiji Red Cross director John Scott had been elevated to international prominence a year earlier for his humanitarian role in supporting the Chaudhry Government hostages following the seizure of Parliament by renegade businessman George Speight and a group of rebel gunmen on 19 May 2000. The hostages were held for 56 days, sometimes at gunpoint. Scott and his long-time partner, New Zealander Greg Scrivener, were found hacked to death at their Princes Road home in Suva on 1 July 2002. After members of Scrivener's family in New Zealand suggested events may have been linked to Scott's humanitarian role and made allegations that the slain men had been tortured, police were remarkably quick to reject speculation on a political motive. ${ }^{1}$ They also made a number of questionable and prejudicial statements while some news coverage was widely condemned as 'sensationalist and homophobic' (Tapueluelu, 2001: 161).

Several international current affairs programmes, including ABC's Pacific Beat (Panichi, 2001), and media commentators challenged the ethics and professionalism of both sectors. Criticism was also levelled over issues such as violations of the legal principles of contempt of court and sub judice. According to Pacific Beat's James Panichi, 'The coverage has some media observers fearing the relationship between police and reporters has become too close for comfort'. The broadcaster asked that while crime reporters may pride themselves on their close relationship with police sources, "where should the line be 
drawn?' The country's most influential newspaper, The Fiji Times admitted in an editorial that the media had gone too far with sensational coverage, adding that the family of Scott had appealed to news organisations to show some 'restraint and sensitivity':

The family's desire is understandable and justified. Parts of the media have been insensitive and less than balanced in their desire to beat their rivals in this most competive of industries. There is little doubt that the Fiji Media Council's code of ethics - drawn up in consultation with the industry - has been breached. Unverified reports, facts sensationalised beyond recognition and pure hearsay have all been seen in the light of day in Fiji's media. We as an industry can and should do better (The Fiji Times, 28 July 2001, cited in Tapueluelu, p 159).

News media coverage of the double murder raised serious questions over ethics, training and professionalism in Fiji, just as when some sectors of the media 'helped to destabilise the government' in the run-up to the Speight putsch (Robie, 2001: 151). The mood among politicians has fluctuated between those who are cynical about the role of the present Media Council, seeking legislation to control the news media, and others who favour revising and consolidating current legislation in the hope that media practices will 'smarten up'. The reformers seem to be in the ascendancy at present.

\section{Draft Fiji media law and foundations of freedom}

Work on a draft new Fiji Media Bill had been going on quietly at the Ministry of Information for more than six years, but had been dusted off by three governments (originally by the Rabuka Government, followed by Chaudhry's Coalition and most recently by Qarase) without actually being enacted (see Robie, 2003: 102-116). In its most recent (Qarase) version, the draft law was not completed in time to be tabled at the final parliamentary session in 2002. However, it was made public by Information Minister Simione Kaitani in May 2003 for consultation and was widely condemned as a crude attempt at control of the media. The draft Media Council of Fiji Bill 2003 provided for the abolition of the existing self-regulating Media Council and its replacement with a Government-appointed council. An expectation that the Government would closely follow recommendations in the Thomson Foundation's 1996 report on the Fiji media legislative framework (Morgan \& Thomas) had been proven 
wrong. The report had been studied by the media and generally accepted and the draft law was expected to include nothing that would curtail press freedom. ${ }^{2}$ Likewise, predictions by media analysts that the proposed law would seek to improve the environment for the media to operate 'freely' (Singh, 2002) were also shown to be misinformed. The Thomson Foundation report had noted that while 'responsible governments and politicians should share a common aim the best interest of their society — their roles are different':

In a healthy democratic society, the relationship between politicians and a free press is, quite properly, likely to be wary, questioning and sceptical, rather than close, cosy or adulatory (ibid.: 5).

The Fiji Government had frequently claimed that it would not introduce laws infringing media freedom, but the public remained sceptical and also critical about the performance of the media. According to former Review editor and media academic Shailendra Singh (2002), in an article provocatively entitled 'Of croaking toads, liars and ratbags', ${ }^{3}$ the media continues to have a credibility problem.

The litany of complaints against the media cannot always be dismissed out of hand. Concerns about unbalanced and unethical reporting, sensationalism, insensitivity, lack of depth and research in articles and a poor understanding of the issues are too frequent and too numerous. Another common complaint is that the media is loath to make retractions or correct mistakes. It has even been accused of bringing down a government or two (Singh, op. cit.).

Among reasons cited for poor standards in Fiji and elsewhere in the South Pacific is that journalists in Fiji are often young, inexperienced and poorly trained. For example, 47 per cent of journalists in Fiji are school leavers with no basic journalism education or tertiary qualifications (Layton, 1995: 137; Robie, 1999b: 183; Singh, op. cit.). However, Singh notes that while there is little argument about this, 'complaints about journalists in Fiji almost mirror those in developed countries where scribes are better trained, more experienced and well paid'. But he argues that there is a broad consensus in Fiji on improving standards because, with the racial and political make-up of Fiji and three coups, an irresponsible media is 'capable of wreaking serious damage'. This was 
indeed a 'major obstacle' after Lieutenant-Colonel Sitiveni Rabuka's military coups in 1987, according to the Thomson Report, with an exodus of senior journalists in the post-coup period, and then made worse after Speight.

The effects are still felt as a missing half-generation of trained, experienced professionals to fill senior editorial and 'long-stop' sub-editorial posts, to act as role models for younger journalists and to provide on-thejob training for new entrants...

We were satisfied that media errors and misjudgements were much more often the result of inexperience than wilful distortion, but that is of limited consolation to their victims.

We encountered on more than one occasion the argument that, if journalists were ill-equipped professionally to exercise the proper freedom of the media, it was not acceptable for them to 'practise on other people's lives' (Thomson Report, 2006: 12).

Many have argued that if freedom is to be meaningful in the modern world, 'it must include some notion of access to the mass media' (Bertrand, 1999: 5; Martin: xi). Perhaps the Fiji law drafters could do well to note the lessons of media self-regulation in Britain and New Zealand (see Elsaka, 2001), and also a Commonwealth document on the issue, Statement on Freedom of Expression for the Commonwealth (1999). Few would argue with its primary declaration:

Freedom of expression means the freedom to receive and impart ideas, opinions and information without interference, hindrance and intimidation. It belongs to all persons and may be exercised through speaking, writing, publishing and broadcasting, or through physical acts.

Freedom of expression is the primary freedom, an essential precondition to the exercise of other freedoms. It is the foundation upon which other rights and freedoms arise (Commonwealth Statement, 1999: 685).

Freedom of expression, argues the document, demands the recognition of journalist unions: 'Journalists' unions have an essential role to play protecting journalists and advancing professional values'. This document has some specific recommendations that are particularly useful in a Pacific context. Referring to journalists as employees, the document says:

Freedom of expression does not belong exclusively to employers and 
managers. Rather, free expression requires that journalists enjoy substantial independence. The terms of employment of journalists should respect and reflect this requirement (ibid.: 690).

The question arises on why there are no effective journalists' unions in the Pacific today, like elsewhere in the world. Teachers, academics, nurses and many other people have professional unions in the Pacific. So journalists arguably should do the same to enhance professionalism and working conditions (Robie, 1999c: 11).

While the Commonwealth document argues press or media councils are a good idea and need to be strengthened and to encourage a trend towards media self-regulation, it adds: 'The tripartite model, structured around the separate and distinct interests of the public, journalists, and media owners or managers is to be preferred' (ibid.: 692).

No Pacific media council follows the tripartite model. Both the Media Council [Fiji] Ltd and Media Council of PNG contrast in their composition with the Australian and New Zealand models, which include independent journalists (in the case of New Zealand, the journalists union, EPMU). The fact that the Fiji council is a company rather than a non-profit non-government organisation is significant. Every news media organisation is directly represented and while there is an equal number of lay members, no independent journalists are members. Nor was the University of the South Pacific Journalism Programme a member during the first nine years of its existence, which as both a publisher and educator in ethics and good practice could have provided an independent perspective. ${ }^{4}$ In the case of Papua New Guinea, the council in the past had no lay members or independent journalists or media academics directly involved, but during 2002 it established an Independent Media Standards Committee (IMSC) to consider complaints.

\section{Case study one: Media Council (Fiji) Ltd}

The Fiji News Council was formed in 1994 as an independent self-regulating media body and was renamed as the [Fiji] Media Council in 1998. Currently it has nine industry members (representing Associated Media Ltd, Communications (Fiji) Ltd, Daily Post Company Ltd, Fiji Broadcasting Corporation Ltd, Fiji Television Ltd, Fiji Times Ltd, Islands Business International Ltd, Sun (Fiji) News Ltd, and USP Journalism), nine public members and an independent 
chairman, former Sugar Industry tribunal chairman Daryl Tarte. Seven public members named in June 2003 are Fiji Women's Rights Movement coordinator Virisila Buadromo, former USP lecturer Parul Vera Deoki, tourism consultant Peter Erbsleben, Suva businessman Waqa Ledua, Ba businessmen Dijendra Singh, Telecom Fiji Ltd marketing manager Salote Uluinaceva, and USP Librarian Dr Esther Williams. Two public member vacancies were being advertised. The council's objectives, as stated on the council's website homepage (including frequent spelling errors), are:

\section{ITS (sic) VERY GOOD NEWS FOR EVERYONE}

To promote high journalistic standards

To enhance the media's image

To safeguard the Medi's (sic) independence

To uphold freedom of speech and expression

To promote a Code of Ethics and Practice for Journalists and Media organisations

To promote an idependent (sic) and effective Complaint Commitee (sic)

Originally the council did not have public members (Robie, 1999a: 14). However, in 1997 the Thomson Foundation report on future media legislation and regulation for Fiji was submitted to the Fiji Government, then headed by Rabuka. The Thomson Report recommendations included establishing a media council with public members and in 1998 the council recruited public members for the first time. One of the significant features of the Media Council in Fiji, especially when compared with its PNG counterpart, has been the reasonably active role of the Complaints Committee (especially in 1998-2000). Tarte also chairs the Complaints Committee. The other two members are businessman Tom Raja and Paula Sotutu. Explaining the committee's role, Tarte wrote:

Some may argue that the Complaints Committee should have more teeth and power to impose fines or other sanctions. However, the council is a voluntary organisation with no legal status. The Complaints Committee judges complaints on the basis of ethics and not law, though these inevitably do overlap. The adjudication takes the form of a reasoned judgement upholding or rejecting the complaints and the media organisations are committed to publishing that adjudication. This is a moral rather than a legal obligation (Tarte, 1997: 4). 
During the Speight putsch and the period of tension over the Chaudhry Coalition Government in the months leading to the crisis, argues Tarte (2001), the council helped to provide some stability. During such crises, he believes, the media becomes serious about self-regulation, about well-established practices of accuracy and balance. Failure to do so 'could bring the wrath and thuggery of mindless rebels down upon them'. Tarte adds:

Throughout the terms of the last Labour Government, the media was under attack from the Prime Minister and his ministers. I firmly believe that had there not been a strong and respected Media Council in existence, the Government would have introduced draconian legislation to impose greater Government control over the media. Our strategy was to try and work with Government and ensure there was dialogue on controversial issues (ibid.).

The council's new code of ethics, launched by Chaudhry in 1999 amid controversy and drafted largely from a report drawn up by Thomson Foundation consultant Ken Morgan, was touted as ushering in a new era in Fiji by introducing a basis for complaints. According to Tarte, Chaudhry's ministers 'referred to them constantly and made countless complaints' (ibid.). However, a closer examination of council adjudications reveals a more complex picture.

\begin{tabular}{|c|c|c|c|c|c|c|}
\hline Year & $\begin{array}{l}\text { Number of } \\
\text { complaints }\end{array}$ & $\begin{array}{l}\text { Settled by } \\
\text { mediation }\end{array}$ & Adjudicated & $\begin{array}{l}\text { Complaints } \\
\text { upheld }\end{array}$ & $\begin{array}{l}\text { Complaints } \\
\text { partially } \\
\text { upheld }\end{array}$ & $\begin{array}{l}\text { Complaints } \\
\text { dismissed }\end{array}$ \\
\hline 2002 & - & - & 1 & 1 & 0 & 0 \\
\hline 2001 & - & - & 1 & 0 & 0 & 1 \\
\hline 2000 & - & - & 5 & 2 & 1 & 2 \\
\hline 1999 & - & - & 6 & 1 & 2 & 3 \\
\hline 1998 & - & - & 3 & 2 & 0 & 1 \\
\hline 1997 & 28 & 26 & 1 & 0 & 1 & 0 \\
\hline Total & - & - & 17 & 6 & 3 & 7 \\
\hline
\end{tabular}

-The Fiji News Council changed its name to the Media Council (Fiji) Ltd in 1998. The last published annual report of the council was in December 1997.

Source: Compiled from [Fiji] Media Council adjudications and the 1997 annual report.

Of the 17 adjudications by the council between 1997 and 2002, seven were declined, six were upheld and three were partially upheld. Half (nine) of the 
adjudicated complaints were filed by cabinet ministers, a Government department or civil servants. Only four were filed by private individuals: a lawyer, a journalism educator (the author) in a test case, and an occasional correspondent for The Fiji Times twice filing similar complaints. Only the correspondent had partial success with his two complaints; the other two private complaints were dismissed. One opposition political party official, one ruling Fiji Labour Party official, a textile industry body, and a college filed the other complaints.

Between them, three Labour-led Coalition ministers - National Planning Minister Ganesh Chand (five), Assistant Information Minister Lekh Ram Vayeshnoi (one) and Assistant Housing Minister John Ali (one) - filed the most complaints (all in 1999 and 2000 before the attempted coup). Although Dr Chand experienced major frustrations with the council, he won one adjudication against The Fiji Times, had one partially upheld and lost one against the newspaper, and won two against Fiji Television. In one complaint against Fiji TV, Dr Chand complained against lack of balance, saying the station's reporters had claimed he did not respond to written questions. Fiji TV claimed that it had faxed the questions to him, but the council found that the station had sent the fax to a private number with no fax link. The council ruled:

While there may well have been an intent by Fiji TV to question the minister before running the story there is clear evidence of carelessness in not sending the fax questions to the right number. The committee is concerned at the 'thoroughness' of the chief executive's investigation when it was a simple matter to check the telephone book (Complaint 99, 2000: 2).

The highest number of complaints were six in 1999 followed by five the following year. Ironically, while there has been heated debate for two years over ethical and professional issues over the coverage of Speight's attempted coup, only two complaints were adjudicated on by the council by the end of 2002, with just one of them related to the political upheaval. Both were dismissed. The Fiji Times faced the most complaints (12), followed by the Daily Post (two), Fiji Television (two), and Islands Business (one). Four of the complaints involved the alleged failure of newspapers to grant a right of reply for balance, eight were for factual inaccuracies and lack of balance, three for distortion and one misrepresentation by a photograph. The Daily Post failed to respond to the council in both complaints against the paper, and it earned a mild rebuke in the 
February 2002 adjudication. The council ruled four breaches of the code of ethics, saying it was

most reluctant to make an adjudication on a complaint when only one party makes a presentation and there is no reply from the other. However, in view of the complete disregard by the Daily Post for the Media Council process for dealing with what was a legitimate complaint, it had no option [but] to proceed with a hearing. The committee is concerned at the disrepect shown by the Daily Post ... (Complaint 118, 2002: 3).

In another complaint, the Daily Post published an apology over a series of illinformed, politically inspired articles leaked by a media organisation with an agenda (Apology,1998). Four years later in a six-page letter to Fiji Media Council chairman Daryl Tarte, media lawyer Richard Naidu (2001) advised the council to overhaul its approach to prevent defects and breaches of its own processes. Critiquing a complaint (112) by the author against Islands Business magazine for breaching two clauses of the council's code of ethics in a report about the closure of the USP journalism website during the Speight crisis, Naidu found that 'in a nutshell, I very much doubt whether the process followed by the council ... would withstand the most basic scrutiny in terms of fairness or due process'. The council's complaints committee declined to uphold the author's complaint in breach of its own code of ethics and procedures. The critique also referred to a double standard by the council, saying that while the author was 'newsworthy' when he sought to invoke the rights of newsworthy people for redress under council rules, he was told that he 'is a media person who should have settled it [by] a different method!' In the year since then, the council had only ruled on one complaint, against the Daily Post. Naidu concluded:

If the Media Council process is to be credible it must be sound. In a couple of cases where clients have come to me complaining about their treatment at the hands of the media I have recommended to them that they use the Media Council procedure because it is supposed to be quicker, to get the real problem and (hopefully) to give the complainants a real solution. If the process [involved in the Robie complaint] is representative of that which the Media Council follows, I would be much slower to counsel my clients that way now (ibid: 6).

In the council's revised code of ethics (2002), just one sentence (s14) deals with 
directly cultural issues, and this stresses chiefly institutions:

While free to report and to comment in the public interest on Fijian chiefly institutions, traditions, affairs and other cultural matters, and on those of other racial or ethnic groups, media should take particular care to deal with these subjects with sensitivity and appropriate respect.

No details are available of the number of complaints actually received by the Media Council, but there is anecdotal evidence of complaints being arbitrarily rejected by the chairman without them being referred to the complaints committee. For example, a complaint by the Citizens' Constitutional Forum to the Fiji Sun that one of its editorial staff had leaked the address of a correspondent's letter to the editor to a 'hostile correspondent', Fijian nationalist and businesswoman Mere Samisoni, was blocked for 'lack of evidence' (Pratt, 2002). Challenging the breach of ethics by the paper, CCF's executive director Rev Akuila Yabaki asked: 'Is it normal for you to reveal the addresses of your correspondents to your letters column when powerful people like Mere Samisoni ask for them?' (Yabaki, 2002).

In January 2003, chairman Tarte briefly resigned from the Media Council, citing lack of commitment by members, adding: 'If they want a council they must be committed to it and take part fully' (Fiji Media Council Chair quits after no shows, 2003), However, he reconsidered after editors pledged their support (Fiji Media Council chair withdraws resignation, 2003).

\section{Case study two: Media Council of Papua New Guinea}

Towards the end of 1995, when Papua New Guinea's Constitutional Review Commission first mooted possible legislation against press freedom, the PostCourier was among the media that greeted the news with more than a degree of cynicism. In a sombre editorial titled PNG HEADED FOR DICTATORSHIP?, the newspaper warned that the move could be the beginning of a drift towards a 'dictatorship style of government' in Papua New Guinea (PNG headed for dictatorship, 1996).

Papua New Guinea's original Press Council was founded almost a decade earlier, in December 1985, with a former judge, John Kaputin, being appointed chairman. Established and funded by the media organisations for 'achieving a better industry and promoting good relations between the industry and the public' (Solomon, 1996: 102), its composition was three industry representa- 
tives from the Niugini Nius (now closed), Post-Courier and Word Publishing; one representative from the PNG Journalists' Association; and two members from the public plus the independent chair. The legislative threat led to the Press Council reinventing itself as the Media Council of PNG, including broadcast members for the first time.

Current president Peter John Aitsi (2002) says most of Papua New Guinea's social indicators are declining. He cites a UNICEF report on Papua New Guinea stating: 'The infant mortality rate for children under one has risen from 67 in every 1000 in 1995 to 79 in every 1000 in 1999.' He points out that in the past seven years, most of the country's 19 provincial governments (including in Bougainville, which was ravaged by a decade-long war) have ceased to function effectively, 'some not even functioning at all'. Evidence of this is claimed in the suspension of provincial governments and lack of local level planning and infrastructure work. Living standards have declined sharply.

\begin{abstract}
I believe there is still a greater tragedy and that is the rampant destruction of the Government machinery resulting in its inability to carry out its obligation to our people. It is my belief that over the years since independence there has been a continued decline in the ability of our communities to help themselves because the flow of resources to facilitate community self help, has been controlled and handed out by their member of Parliament. So in some areas we have created virtual 'cargo cult' communities where development is tied to their National Parliament representative (ibid.).
\end{abstract}

Aitsi asked what could the media do with this information. The Media Council through its members has committed itself to try and get this information into the hands of the communities so they could be informed and hopefully empowered to scrutinise the performance of their elected representative. These factors also lie behind the media council's successful campaign against corruption, in partnership with Transparency International and the Ombudsman's Office.

Although the Media Council of Papua New Guinea has been operating in various forms for almost two decades, the formal complaints structure was only established in 2002, some eight years after Fiji. Originally, media companies 'came together as a loosely formed group to discuss problem accounts and other issues', including a move by then Communications Minister Martin Thompson to introduce legislation to regulate the media (ibid.). 
This regulatory move by the Government became the turning point enabling the Media Council in PNG to unite news media groups. The agreement to work together was reinforced during the staging of the 1995 Pacific Islands News Association (PINA) conference in Port Moresby. This event encouraged PNG media to work together to plan, prepare and host other media organisations from around the region. Membership now comprises two national daily newspapers, PNG Post-Courier (predominantly owned by Rupert Murdoch's News Ltd) and The National (owned by Malaysian timber company Rimbunan Hijau); a weekly national newspaper, Wantok (Word Publishing, locally owned ecumenical company); a national free-to-air broadcaster, EMTV (wholly owned by Packer's Channel Nine in Australia); the state-owned National Broadcasting Corporation (NBC), which operates national AM and FM broadcast programmes in some cities; PNGFM, a nationwide FM broadcaster with three stations managed by Communications (Fiji) Ltd; and several smaller broadcasters and publications. Anna Solomon, then acting publisher and general manager of the Word Publishing Group and now retired, became president of the Media Council in 1995.

She is a great person and still an inspiration to the young people in our industry. I believe the changing focus of the council can be greatly attributed to Mrs Solomon's leadership (Aitsi, op. cit).

In 1997, former Post-Courier editor Luke Sela was elected president and he continued to strengthen the Media Council's expanding training programme. Three years later Aitsi was elected president. The same year, the council became formally registered and its constitution was adopted. The council then began drafting a code of ethics by researching other codes and then commissioning a consultant to review the codes for consideration by editors, journalists and media workers. Community groups were also consulted. The final review involved another consultant. The lengthy process was followed to ensure that the code had 'credibility in the eyes of users and the community' (Aitsi, op. cit.), a contrast with Fiji. The Code of Ethics has now been printed and circulated to all newsrooms as well as being incorporated into the journalism and media studies courses at the University of PNG and Divine Word University.

Attempts made by the PNG Government to regulate the media are still a real threat and something that the industry has been actively working against. After two years of consultation, a five-member Independent Media Standards Com- 
mittee (IMSC) was launched after the 2002 general election. Appointed as inaugural chair is Winifred Kamit, lawyer and president of the PNG Institute of Directors. Others appointed are deputy chair Tas Maketu, secretary-general of Caritas PNG/Churches, Anne Kerepia of the National Council of Women, businesman Richard Kassman of Transparency International, and law academic Dr John Luluaki, of the University of Papua New Guinea. On top of the Code of Ethics and the IMSC, the media council has continued to plan and implement a domestic and international training calendar for media industry staff.

It is our intention to demonstrate to the public, and particularly to the Government, that we are not a 'power unto our own' and that we are open to public scrutiny and comment. This openness, we hope, will work against the threat of any possible future move by governments to regulate or control the media of PNG (Aitsi, ibid.).

\section{Conclusion}

Pressures and dilemmas for the news media continue to gain momentum in the South Pacific, often from a cultural as well as a political dimension. While the media in some countries are refreshingly outspoken and courageous, in others there is a worrying trend towards self-censorship. Some media industry observers argue that reclaiming Pacific images and 'envisioning a future without coups, conflicts and contraband' is now more urgent than ever (Thaman, 2001: 8). This is due to a perception that the dominant news media in the Pacific is 'Western', with Eurocentric and north-based conceptual models dominant. However, these models have failed to seriously take Pacific and indigenous cultures and their world views into account. Yet Pacific news media have played a crucial role in exposing corruption and abuse of political power or office, and in some cases leading to redress. It is vital that no political or social institutions have absolute authority over it. There is also the hegemony of news media organisations themselves at stake.

The conflict between media and its critics in the South Pacific may be summarised, in general, as having two schools of thought. From one perspective, while there is acknowledgement that there are shortcomings in the professional expertise of some media and journalists, the solution lies in a régime of self-regulation and self-help strategies. A second perspective argues that self-regulation has manifestly failed and that it is no longer acceptable for the media to be 'judge and jury at their own trial' (Thomson Report, 1996: 18). 
Efforts by both the Media Council (Fiji) Ltd and the Media Council of Papua New Guinea have met mixed results and have contrasted in style. Although the [Fiji] Media Council has been long-established, it closely follows Western models and has adopted a 'top down' code of ethics while excluding representation of independent journalists. In effect, it is more of a 'closed shop' and less independent of the hegemonic power of local media organisations than its counterparts in Australia and New Zealand. The complaints process also appears flawed and lacking credibility, considering the big fall off in adjudications. On the other hand, while the [PNG] Media Council has been slow to open up the 'club' to lay representation, it has been more innovative in training and with its independent complaints tribunal (IMSC) in an attempt not to be seen as 'power unto our own'. It has also been more culturally responsive to grassroots community concerns and working journalists themselves in drafting a homegrown 'bottom up' code of ethics. Codes that are 'owned' by journalists themselves are more likely to be observed and respected.

Other Pacific nations considering media councils ought to allow more time to weigh up the merits of the contrasting models. They ought to also consider the tripartite model as suggested for the Commonwealth. Both the Fiji and PNG media council models have been effective in defending press and broadcasting freedom in the face of Government pressures, but in terms of being a credible cultural and public rights safeguard the jury is still out.

\section{Notes}

1 The man accused of the Scott double killing, Apete Kaisau, wasin August 2003 found not guilty by the Fiji High Court at Suva by reason of insanity. The schizophrenia suffererer was ordered by the court to be detained indefinitely in a Fiji psychiatric institution. [Insanity verdict in Fiji. (2003, August 6). TVNZ One News/Reuters.] onenews.nzoom.com/onenews_detail/0,1227,211446-1-9,00.html (Retrieved $8 \mathrm{Au}$ gust 2003).

2 In fact, when Information Minister Simione Kaitani eventually unveiled the draft Media Council of Fiji Bill in May 2003 and called for public submissions, the document included punitive clauses and was immediately embroiled in controversy. The news media industry bitterly opposed the draft law as 'draconian' and civil society groups were also opposed, some describing it as 'unconstitutional'.

${ }^{3}$ The quote is cited in John Hurst and Sally White's Ethics and the Australian Media and is attributed to 18th century English political journalist William Corbett who likened reporters to a parcel of toads that, when disturbed by a brickbat, 'turned upon their backs ... showing their nasty white bellies, and all croaking out their alarm, 
emitting their poisonous matter'.

4 However, this changed in May 2003 when USP became a member of the Media Council as a publisher with rule changes. (USP Journalism becomes Fiji Media Council member, USP Beat, Issue 8, June 3, p 3).

\section{References}

Aitsi, Peter John (2002). Media and Politics in PNG. Paper at the Foundation for Development Cooperation's Pacific Development Research Symposium, Brisbane, 22-24 July 2002.

www.fdc.org.au/files/aitsifinal.pdf (Retrieved 9 January 2003).

Apology [to David Robie] (1998, November 30). Fiji's Daily Post, p 6.

Bertrand, Claude-Jean (1999). About press councils in Europe. Paper presented at the British Press Complaints Commission seminar, Promoting Self-Regulation. June 10. Cass, Philip. (2002). Baptism of Fire: How Journalism Students from the University of the South Pacific covered the Speight Putsch and its Aftermath. The Round Table, September, 366: pp 559-574.

Complaint No 118 Adjudication - Public Service Commission vs The Daily Post (2002). Fiji Media Council, February 18.

Complaint No 112 Adjudication — David Robie vs Islands Business (1998). Fiji Media Council, October 9.

Complaint No 112 to the Fiji Media Council (2001). USP Journalism Coordinator vs Islands Business, an independent critique of the adjudication by media lawyer Richard Naidu, of Munro Leys, and other papers.

Complaint No 99 Adjudication - Minister of National Planning vs Fiji Television (2000). Fiji Media Council, February 18.

Editorial: PNG headed for dictatorship? (1996), Post-Courier, cited in Pacific Journalism Review, 3 (2): 5.

Elsaka, Nadia (2001). The politics of voluntary restraint: The development of selfregulatory codes by the British and New Zealand print media. Australian Journalism Review, v 23 (2), pp 149-165.

Field, Michael (2002). Pacific Journalism: Reflections from a Journalist in the Field. In McGregor, July, and Comrie, Margie, What's News: Reclaiming Journalism in New Zealand (pp 233-243). Palmerston North: Dunmore Press.

Fiji journalists are 'mad, crazy loonies', says senator (2002, August 29). Wansolwara Online.

www.usp.ac.fj/journ/docs/news/wansolnews/2002/2002august/wansol2908022.html (Retrieved 10 January 2003).

Fiji Media Council Chair quits after no shows (2003, January 24). PINA Nius Online. www.pacificislands.cc/pm122001/pinadefault.cfm?pinaid=6948 (Retrieved 11 February 2003). 
Fiji Media Council chair withdraws resignation (2003, January 31). Pacific Media Watch. www.asiapac.org.fj/cafepacific/resources/aspac/fiji3924.html (Retrieved 11 February 2003).

Fiji Media Council complaints and decisions (2002). University of the South Pacific Journalism Programme's Online Classroom. www.usp.ac.fj/journ/docs/ethics/fjmc.html (Retrieved 7 January 2003).

Fiji Media Council home page (2002). It's very good news for everyone. www.fijimediacouncil.com/ (Retrieved 10 January 2003).

Fiji News Council (1997). Complaints 1997. In Fiji News Council Annual Report No 2, December 31.

Fiji News Council Submission to the Ministry of Information, Broadcasting, Television and Telecommunications on Future Media Legislation and Regulation (1996). Fiji News Council.

Gramsci, Antonio (1971). Selections from the Prison Notebooks. London: Lawrence and Wishart.

Helu, 'I Futa (1995). Foreword: The Media, Morality and Culture. In Robie, David (ed), Nius Bilong Pasifik: Mass Media in the Pacific (pp 1-4). Port Moresby, Papua New Guinea: University of PNG Press.

Hussain, Bernadette (2002, September 2). Abuse of House privilege. The Fiji Times, p 7.

Layton, Suzanna (1995). The demographics of diversity: Profile of Pacific Island journalists. Australian Studies in Journalism, 4: pp 123-143.

Martin, Robert (1999). Speaking Freely: Expression and the Law in the Commonwealth. Toronto: Commonwealth Association for Education in Journalism and Communication, and Irwin Law.

Meadows, Michael (1998). Making journalism: The media as a cultural resource. Australian Journalism Review, December, 20(2): 1-23.

Moala, Kalafi (2000). Tonga and the independent press. Paper prsented at the First Oceania Conference of the Word Association of Press Councils (WAPC), 21-23 June 1999, p 3.

Moala, Jale (2001). Political reporting and editorial balance. In David Robie (ed),The Pacific Journalist: A Practical Guide (pp 125-143). Suva, Fiji Islands: Journalism Programme, University of the South Pacific.

Morgan, Kenneth, and Thomas, John Prescott (1996). Future Media Legislation and Regulation for the Republic of the Fiji Islands. Consultancy Report. Cardiff: The Thomson Foundation.

Naidu, Richard (2001). Communication to Chairman of Fiji Media Council, November 13.

Panichi, James (2001, August 2). How close is too close for police-media relations? ABC Pacific Beat. www.abc.net.au/asiapacific/focus/pacific/ GoAsiaPacificFocusPacific_339884.htm (Retrieved 10 July 2002). 
Pratt, Bob (2002, September 9). Fiji Media Council letter to CCF executive director Rev Akuila Yabaki.

Robie, David (1999a). Australian Press Council Fellow: David Robie, Report and Speeches. An Occasional Paper series. Sydney: Australian Press Council.

Robie, David (1999b), Pacific newsrooms and the campus: some comparisons between Fiji and Papua New Guinea. Australian Studies in Journalism, Issue 8: 176-196.

Robie, David (1999c, July 11). Free press is a universal value. Fiji's Daily Post, p 11. Robie, David (2001). Coup coup land: The press and the putsch in Fiji. AsiaPacific MediaEducator, January-June, No 10, pp 148-162.

www.uow.edu.au/crearts/journalism/APME/contents10/APME_SET.pdf (Retrieved 8 January 2003).

Robie, David (2003). Journalism Education in the South Pacific, 1975-2003: Politics, Policy and Practice. Unpublished doctoral dissertation. Suva: History/Politics Department, University of the South Pacific.

Singh, Shailendra (2002). Of croaking toads, liars and ratbags. Wansolwara, Vol 7, No 4. $\mathrm{p} 6$.

www.asiapac.org.fj/cafepacific/resources/aspac/fiji3822.html (Retrieved 8 January 2003).

Solomon, Anna (1996). The Past and Present Role of the Papua New Guinea Media Council. In Millett, John (ed), Freedom at the Crossroads: Media and the Constitution (pp 102-105). Port Moresby: Institute of National Affairs.

Statement on Freedom of Expression for the Commonwealth (1999). In Martin, Robert (1999). Speaking Freely: Expression and the Law in the Commonwealth (pp 685692). Toronto: Commonwealth Association for Education in Journalism and Communication, and Irwin Law.

Tarte, Daryl (1997). Fiji News Council: Annual Report No 2, December 31.

Tarte, Daryl (2001). Media councils in an unstable political climate. Paper at AsiaPacific Regional Press Freedom seminar, Sydney. October 1-2. www.presscouncil.org.au/pcsite/meetings/report.html (Retrieved 9 January 2003).

Tarte, Daryl (2002, September 19). Media statement. Media Council (Fiji) Ltd. www.FijiMediaCouncil.com/news.html (Retrieved 9 January 2003).

Thaman, Konai Helu (2001). Reclaiming Pacific images: A View of Communication and Peace. Paper presented at an International Association for Mass Communication Research (IAMCR) Conference, Budapest, September 6-10.

The [Fiji] Media Council: Media Release (1999, February 11). Media Council (Fiji) Ltd. The [Fiji] Media Council: Its (sic) very good news for everyone (2002). Fiji Media Council Ltd. www.FijiMediaCouncil.com (Retrieved 7 January 2003).

The [Fiji] Media Council General Media Code of Ethics \& Practice (1999). Suva, Fiji Islands: Media Council (Fiji) Ltd 
The Media Council of Papua New Guinea (2002). Untitled membership and constitution.

www.postcourier.com.pg/mediacouncil/media01.htm (Retrieved 7 January 2003). Tapueluelu, 'Anna (2001). Reporters and the police - too close? Pacific Journalism Review, 7(1): 159-163.

Yabaki, Rev Akuila (2002, July 29). Letter to the editor of the Fiji Sun.

David Robie is a senior lecturer in Journalism at Auckland University of Technology's School of Communication Studies. He was previously journalism coordinator at the University of the South Pacific 1998-2002. He was Australian Press Council Fellow 1999. This refereed article was originally presented at the Between Empires: Communication, Globalisation and Identity Conference at AUT, 13-15 February 2003.

david.robie@aut.ac.nz www.asiapac.org.fj

\section{Call for papers - Jeanz 2003}

The Journalism Education Association of New Zealand (Jeanz) would like to invite papers for its 2003 annual conference. The conference, to be held at the Western Institute of Technology, New Plymouth, on December 4-5, will be built around the following theme: The Odd Couple: Academic Degrees Versus Skills-Based Training (title borrowed from a paper by Penny O'Donnell in Australian Studies in Journalism).

Papers on all journalism topics will be considered, but preference may be given to those that deal with the practical aspects of journalism education, or which offer an academic reflection on issues pertaining to journalism training. There is space for eight papers, with half-an-hour allotted to each (45 minutes available for some). The time allocation includes question time. If the number of papers accepted exceeds eight, consideration may be given to running papers concurrently. Abstracts due with Ruth Thomas at AUT (ruth.thomas@aut.ac.nz) by Friday, October 3, with at least a welladvanced draft of the actual paper due with Ruth by Friday, November 14 .

See website: www.jeanz.org.nz

See you there.

\section{David Venables}

President, Journalism Education Association of NZ (Jeanz) 